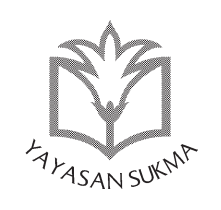

SUKMA: JURNAL PENDIDIKAN

ISSN: 2548-5105 (p), 2597-9590 (e)

Volume 2 Issue 1, Jan-Jun 2018, hlm. 25-65

https://jurnalsukma.org/index.php/sukma/article/view/02102

\title{
PARENT INVOLVEMENT IN SCHOOLING PROCESSES \\ A Case Study in Aceh
}

Dwi Wulandary; ${ }^{1}$ Herlisa $^{2}$

${ }^{1}$ School of Education, University of Tampere, Tampere, Finland ${ }^{2}$ Sukma Bangsa School, Aceh, Indonesia email:dwiwulandarysiddik@gmail.com

\section{Abstract}

The study focuses on exploring the parents' understanding of their involvement in schooling processes based on the six typologies of Epstein. The categories of the study were based on the typologies of Epstein consisting of parenting, communicating, volunteering, learning at home, decision-making, and collaboration with the community. Parent involvement in an Aceh school is a crucial issue which needs to be studied. This research provides an analysis of parents' understanding of their involvement in schooling processes, what 
different kinds of ways parents/homes and school communicate between each other, and whose parents are frequently involved in schooling. There are several barriers parent involvement in schooling, such as work demands, reluctance to attend the school, lack of communication with the school, and parents' perception of their involvement. The reason behind parent involvement in schooling processes can be explained with attribution theory. The findings indicated that parent involvement in schooling processes in Aceh is low. In addition, the motivation of parents to be involved in schooling processes was related to their own motives, such as merely to fulfill their obligation as a parent in rearing the children.

[Tujuan penelitian ini adalah untuk mengeksplorasi pemahaman orang tua tentang keterlibatan mereka dalam proses pendidikan berdasarkan enam tipologi Epstein. Kategori penelitian ini berdasarkan tipologi Epstein terdiri dari pola asuh, komunikasi, relawan, pembelajaran di rumah, pengambilan keputusan, dan kolaborasi dengan masyarakat. Keterlibatan orang tua di Aceh merupakan isu penting yang perlu diperhatikan. Penelitian ini memberikan analisis tentang pemahaman orang tua tentang keterlibatan mereka dalam proses pendidikan, bagaimana cara orang tua dan sekolah berkomunikasi satu sama lain, dan apakah ayah atau ibu yang dominan terlibat dalam pendidikan anak mereka. Ada beberapa hambatan keterlibatan orang tua di sekolah, seperti tuntutan kerja, keengganan untuk bersekolah, kurang komunikasi dengan sekolah, dan persepsi orang tua terhadap keterlibatan mereka dalam proses pendidikan. Alasan di balik keterlibatan orang tua dalam proses pendidikan dapat dijelaskan dengan teori atribusi. Penelitian ini menemukan bahwa keterlibatan orang tua dalam proses pendidikan di Aceh rendah. Selain itu, motivasi orang 
tua untuk terlibat dalam proses pendidikan itu terkait dengan motivasi mereka sendiri, seperti semata-mata memenuhi kewajibannya sebagai orang tua dalam membesarkan anak.]

Keywords: Aceh, parent involvement, Epstein typology, parents' perceptions.

\section{A. Introduction}

Parents have a very significant influence on their children's development. Consequently, parents have the important responsibility to lead and support their children's development. Parents should create a pleasurable environment so that children's potential and self-confidence can develop well. Moreover, parents should also have an active role in their spare time for their children, including attending and following school programs. On the other hand, school as formal education helps children learn about socialization, communication, and develops their academic ability.

Additionally, the responsibilities of parents for their children's education will be reduced when they enroll their children in school. Therefore, parents may fully devolve their children's learning process to the school. Parents' perception of their role is only taking children to school, after which then the school has the responsibility to educate their children, so that parents are less engaged to participate in supporting their children's education both at home and at school (Hornby 2011). Parents decided to choose the best school for their children, they assumed that this would be adequate to guarantee the success of their children without the need for their further involvement. This implies the school has full responsibilities in the learning process. However, since children's success also depends on parent involvement, a school should provide more programs involving parents (Smith et al. 2006).

First and foremost, parent involvement in their children's 
education is not only at home but also at school. Parents' participation in their children's education at home includes motivating their children to learn, creating a conducive environment at home, monitoring their learning, and assist them in doing homework. On the other side, parent involvements at the school include their willingness to attend school events, initiative to communicate with teachers, and contribution in providing suggestions to support the school policy.

Several studies have found that there is a relationship between parent involvements in schooling with their children's achievement. Fan and Chen (2001) as cited by Yoder and Lopez (2013) also argued that parent involvement in education is one of the major factors in enhancing students' academic achievement and promoting their positive behavior. The ability of children at school will be better when parents are involved in schooling (Georgiou 1997). Similarly, in another study, Georgiou (1997) found that parent involvement which includes assistance in doing homework and involvement in school programs has a correlation with student success.

As Indonesian Law Number 20, 2003, on the national education system, in the second part of Subsection 7 about the rights and duties of parents stated: "(1) Parent have the right to participate in choosing education units and to receive information about their children's educational development. (2) Parents of compulsory school-aged children are obliged to provide basic education to their children." Werf, Creemers, and Guldemond (2001, 449) remarked that "in Indonesia, parent involvement was seen as an important aspect in increasing the quality of education in order to have better student outcomes". However, do Indonesian, especially Acehnese parents know what importance their involvement in schooling processes? Is there any guarantee that parent involvement is also occurring in Aceh?

Numerous studies in Indonesia about parent involvement indicate several factors that cause parents' lack of involvement in schooling processes. Parents' lack of involvement is mainly 
caused by the low social economic factor and conflict within the family (Sandjaja 2001). Moreover, economic crises and natural disasters in several regions in Indonesia cause conflicts within families (Yetti 2009). Mental stress experienced by parents due to the conflicts reduces their capacity to develop and sustain their children's interest in reading. Hence, the children's development is not optimal. However, parent involvement has received little attention.

The fact that parent involvement in Aceh in schooling processes is still low can be observed from the school's perspective. One of the factors that leads to a lack of parent involvement is the ignorance of participating in school events. On these occasions, most of the parents cannot attend the school's events such as attending the Parent Teacher Association (PTA) meetings, school fair, and bazaar. The parents also do not participate well in school programs because they are busy with their jobs or fail to see the schedule of school events. It can also be said that there is a lack of communication between parents/homes and school with each other. As a consequence, a relationship between parents and school through communication is important to deliver the information in supporting school programs in schooling processes.

Most of the parents in Aceh, in the scope of Sukma Bangsa School, think that their involvement in schooling processes is less important. Evidence of this fact is that the presence of parents in the PTA in 2016-2017was only 74\% of parents. We think for those $74 \%$ of parents attending school is quite enough. But, it would be better if $100 \%$ of parents were involved. For this reason, we would like to explore the parents' understanding in Aceh about their engagement in education. Therefore, the parents could realize that their involvement at school can improve their children's academic achievement. Similarly, this study can make parents/homes closer to the school. This study focuses on the perception of parents' involvement in learning in Aceh. In this study, we address the question more broadly; what is parents' understanding about their involvement in the educational process, what different kinds of ways parents/homes 
and school communicates with each other, and whose parents are frequently involved in schooling?

This research used a qualitative case study approach to the exploration and interpretation of parent involvement in schooling processes within a real-life context. A qualitative case study is defined as the profound study of a phenomenon close to us (Stake 1995, as cited in Brown, et al. 2009). The key informants in this study were 16 parents of students from grades VIII and IX. The data was gathered by using semi-structured open-ended interviews and document reports.

Each of the interviews was recorded and transcribed verbatim. Then the transcripts were coded into six typologies of Epstein of parent involvement (Sanders and Epstein 1998) and interpretative phenomenological analysis (IPA) was applied. The process of analysis began with rereading the transcript several times in order to gain a deeper understanding of the meaning. Additional information was given by the parents based on their experiences at school and when they become parents. Therefore, it was also intended to reveal the effect of phenomenology in relation to parent involvement.

\section{B. The Concept of Parent Involvement}

Parent involvement is the essential factor in improving the knowledge and supports children's education. It is referred to as the relationship between parents and children that plays a part in their children's progress and also leads the parents to take part in schooling processes (Reynolds 1992). In general terms, parent involvement is defined as representing “...parents' active commitment to spend the time to assist in the academic and general development of their children" (Borgonovi \& Montt 2012, 20 as cited by Daniel, Wang \& Berthelsen 2016).

Similarly, Fantuzzo et al. (2004), as cited by Yoder and Lopez (2013) define parent involvement as communication between home and school, supporting learning at home, participating in school activities, and having a voice in deci- 
sion-making practices within the administrative structure. The development of children in learning progress can be identified by such indicators as better grades, attendance, and a good attitude. It can be monitored through good communication between parents and teachers. One form of parent involvement in school is communicating with teachers. Communication can be a bridge for parents to get involved in children's education. In essence, parents have an obligation and responsibility to carry out the education of their children. The role of parents in the learning process can influence children's development. For this reason, the quality of education can be improved by involving parents in education.

Essentially, Parent involvement is necessary to improve the academic achievement of students. When the parents get involved in the learning process, the children will be motivated to do better at school. Wood (2003), as cited by Ibrahim and Jamil (2012), showed that parents who are involved in the school process of their children will enhance academic success at school. Participation of parents in learning, such as assisting their children in doing homework or assignments from school, being a volunteer, contributing through support and affirmation of their children's achievement can be identified by better grades, attendance, attitudes, and homework completion (Smith, Wobhlstetter \& Pedro 2011). Reynolds $(1992,446)$ states that "The indicator of PI obtained from parents, teachers, and children regard potentially enriching interactions with the child at home or in support of the child at school". Intense contact with children at home and facilitating them in school is also included as an indicator of parent involvement.

Additionally, Olmstead (2013) classified parent involvement into reactive and proactive involvement. Reactive involvement means parents attend to school programs that are organized by the school such as parents' meetings, family gatherings, or volunteering whereas proactive involvement is the participation of parents in assisting their children, completing homework, discussing school activities, and following the chil- 
dren's improvement. In conclusion, parents need to be aware of their roles and responsibilities in educating their children. The desire to engage in any activity related to their children's education both at home and in school involvement should be owned by each parent.

The concept of parent involvement in this part is clear based on the definition of the authors that emphasizes its the different aspects. It is related to the multiple perspectives that are influenced by their lived experiences. An explanation of the types of parent involvement both at home and at school will be explained in the next sub-section.

The study of parent involvement considers the theoretical framework of Epstein. She has developed the most reputable framework about parent involvement which defines six types of parent engagement (Epstein 2010; Epstein et al. 2002; Epstein 2001,2011 ) and served as the frame of our study through exploring parent involvement at home and also at school. Henderson and Mapp (2002), as cited by Patrikakou and Anderson (2005) claimed that parents' engagement is often classified into two broad categories: "at home" and "at school". It shows how parents are able to be involved in the schooling process, as well as to examine whose parents are active or not in involving themselves in their children's learning process.

Epstein's framework, categorizing parents' engagement related to the school-family-community model into six types, was derived from the theory of overlapping spheres of influence (Epstein 1995 as cited by Sanders \& Epstein 1998, 4; Ibrahim \& Jamil 2012, 39; Smith, Wohlstetter, Kuzin \& Pedro 2011, 77). Sanders and Epstein (1998, 4) said:

The six types of involvement are: 1) parenting --helping all families establish home environments that support children as students; 2) communicating designing and conducting effective forms of communication about school programs and children's progress; 3 ) volunteering recruiting and organizing help and support for school functions and 
activities; 4) learning at home providing information and ideas to families about how to help students at home with school work and related activities; 5) decision-making including parents in school decisions, and 6) collaborating with the community identifying and integrating resources and services from the community to strengthen and support schools, students, and their families.

Basically, the above shows specific responsibilities of parents. Each type of engagement of parents or relationship between parents and school has different outcomes for students. The type of the basic obligations at home is parenting. However, communicating is the basic obligation at school. Therefore, parent involvement in the schooling process consists of homebased involvement and also school-based involvement (Sui-Chu 1996; El Nokali et al. 2010; Strickland 2015).

\section{Parent Involvement at Home}

Parent involvement at home can be categorized into parenting and learning at home. Firstly, families have a responsibility in providing for the health of their children and setting up a home which is acceptable for study. In any case, a mother has an enormous role in assisting their children at home rather than a father. Conrade and Ho (2001), as cited by Alsheikh, Parameswaran, and Ethoweris (2010) found that the parenting style of a mother had a bigger influence on the acts of children in school at Bronte-Tinkew. Another possibility, Moore and Carrano (2006), as cited by Alsheikh et al. (2010), found that the parenting style of fathers' emotional awareness was related to actions of their children as well. Therefore, parents' participation at home will foster the motivation of their children in schooling.

Secondly, the participation of parents at home is assisting their children in learning at home. This engagement consists of the control and support of learning. For example, control of learning is asking if the children have homework or assignments from 
school, suggesting to their children to finish their homework, reciting the Quran, knowing of their children's activities, looking for activities for their children and choosing friends for their children. On the other hand, support of learning is giving the facilities such as a smart phone, the internet, and a laptop. Then, parents are also providing additional learning, reciting the Quran, and asking about difficulties in doing homework from friends or neighbors who have more understanding. Finally, parent involvement at home is not only parents' responsibility for health and safety, but also in doing homework. It has a close relationship to their behavior. Hayes (2011), as cited by Strickland (2015), said that home-based involvement is the ways parents educate their children at home that enhance their children's academic achievement.

\section{Parent Involvement at School}

One of the forms of parent involvement at school is communication between parents and teachers. Through communication, parents can discuss their children's achievement and attitude. In addition, teachers can also know the children's problems at home and how to encourage them in learning. Therefore, the communication of parents helps in understanding their children's learning ability, and helps in solving their children's problems at school and constructing their children's behaviors. Then, parents can guide their children's development in the educational process at school. Furthermore, parent involvement is able to motivate and promote the self-confidence of student. This issue will be a factor which encourages students in learning. Eventually, the quality of parent involvement will facilitate the effectiveness of a student's academic achievement.

Specifically, the school made an appropriate program and organized events to involve parents in the schooling process. One of the school programs is communication with parents. Teachers should make a relationship with parents in providing the information about their child. In addition, the school explains 
to them about policies, the school's programs, the school's rules, and the school's regulations. Furthermore, they also advise them about their children's progress. Therefore, the parents should take their time to attend the school's events and initiate effective communication with the teachers. Additionally, parent involvement in the schooling process helps the school create strategies and programs so that parents can be more engaged.

\section{Parents' Perceptions of Their Involvement}

The perception of parents commonly happens when enrolling their children in school. They perceive that their obligation as parents has been completed in terms of learning, and that furthermore, the school has the function and responsibility to provide their children with knowledge. When the children are in school, this part of the parent's responsibility is reduced, so that they only need to execute their other role. This leads to an imbalance between expectations and action. If parents want their children to succeed, their role should be more active in fulfilling the basics of their children's needs. Parents' engagement in the learning process of their children includes assisting children with homework, attending school activities and discussing with the

school to inquire about the development of their children in school. Through this involvement, the children will be motivated and will have enhanced self-confidence to do their best in school and at home. Epstein $(1987,121)$ stated that parents train the children at home by constructing "self- confidence, self-concept, and self-reliance" to promote their achievement in schooling. Not only do parents have the responsibility to cultivate these aspects, but also the school has the same responsibilities when children are at school.

\section{Benefits of and Barriers to Parent Involvement}

Parents' involvement either at home or at school has an effect on enhancement of the children's academic achievement. 
This is supported by research by Houtenville and Conway (2008), who found that the parents' effort has a direct impact on the student's attainment (Fan \& Chen 2001; Epstein et al. 2002). The children will be motivated to learn when their parents care and are directly engaged in the learning process. Therefore, they will be more enthusiastic about learning. In addition, a high student academic achievement can be seen in the student's grades concerning all learning activities. Pinantoan (2013), as cited by Sapungan (2013), stated that there is a strong influence of parents' engagement on a student's academic achievement. Lee (1994), as cited by Epstein (2010), found, by using longitudinal data and accurate statistical controls, that parent engagement has important benefits for the children's attitudes, behaviors, and grades in junior high school through senior high school. Likewise, parents will motivate the children to enhance their discipline, including attendance at school. Moreover, when parents build a positive relationship through active communication with the homeroom teacher it will help them to know about their children's condition faster.

Secondly, children have a sense of well-being when parents have care and concern for them. A strong sense of wellbeing means a combination of physical, social and emotional factors. Parent involvement at home such as motivating children to learn and constructing a comfortable home condition has an essential influence that helps children to feel happy all the time and be free of illness. In addition, parents' engagement in promoting social factors will have a positive influence on a student's behavior. Thirdly, can parents assist in completing homework or assignments from school? Hoover-Dempsey and Sandler (1995, 1997), as cited by Hoover-Dempsey et al., (2001), argued that there are three main reasons that parents engage in their children's homework, as follows: parents believe they should be involved and it will create a positive improvement, and also they feel there it provides an invitations for involvement. Furthermore, help in doing homework is also one of the ways that intensifies the time spent by parents and students together. 
Lastly, parents assume that if they have trust in their children's education it will make better expectations for them in the future, because the ambitions of children will be increased when parents get involved more in their education. Furthermore, parents also assume they will have a better perception of the classroom and the school climate of their children. The children will also be enthusiastic to learn if they feel comfortable with the classroom conditions, such as cleanliness and orderliness. The school climate also supports learning, such as school culture; no cheating, no bullying, and no smoking. Therefore, parents have a high contribution to make to their children and the school, and parent involvement can help teachers in the learning process.

The potential barriers to parent involvement can be categorized into four areas to try to explain and elaborate on the difficulties of parents. First, family factors, which include parents' beliefs about getting involved in their children's education; parents' attendance in school's events, parents' life context, and parents' backgrounds, such as social class, ethnicity, and gender. Second, factors related to the children's age, barriers in learning and disabilities, rewards, and aptitudes, and also problems in attitude. Next, factors of the relationship between parents and teachers, related to managing purposes and schedules, interacting with other and using effective language. Finally, factors of the social environment related to historical and demographic, political and economic issues.

\section{Parent Involvement in the Aceh Context}

Aceh has a long history associated with conflict and natural disasters. During the conflict, many schools were burned, while the earthquake and the tsunami not only destroyed school buildings but also the lives of children and adults. It is estimated that the impact of the tsunami was that more than 2.000 schools were destroyed, 2.500 teachers died, and 160.000 children could not attend school (Common wealth of Australia 
2008, cited by Shah \& Kardozo 2014). Education is one area that is very important in the work on the reconstruction of Aceh after the tsunami on December 26, 2004. The field of education includes both rebuilding educational facilities, thousands of school buildings destroyed by the tsunami, and human resources.

Damage and loss of educational staff have a great impact on the lives of the people of Aceh. Most Aceh children experienced a loss in education. Furthermore, they had serious trauma psychology after the tsunami. Education is important in rebuilding Aceh, giving chances for the children to study and build their futures. Consequently, rebuilding the education sector is one of the fundamental aspects of the process of rehabilitation and reconstruction of Aceh after the earthquake and tsunami. Hence, the Aceh government, together with the private sector and foreign institutions has given great attention to rebuilding the educational facilities in Aceh.

In the context of Aceh society, the involvement of parents in teaching children religious education is more viscous. Parents are more involved in supporting the education of children in reciting the Quran than in learning in school. According to Samad (2015), parents have the obligation to enroll their children to learn the Quran when they are about six or seven years old. Acehnese will feel like a failure and sinful if they are unsuccessful in teaching their children to read the Quran. Acehnese people have different perceptions about education. Nowadays, awareness of the importance of education has been better. If compared with the previous era, when education was not an important priority, and thus, the involvement of the parents in education was very low. However, in parent involvement in the context of Acehnese society the relationship between fulfilling the needs of daily life and children's education is not balanced. Most parents are more concerned with the fulfillment of daily needs rather than assistance in learning. Lack of parent participation in schooling occurs not only in Aceh province but also occurs in other provinces in Indonesia. 
According to Majzub and Salim (2011), parent involvement in private kindergartens in Curug district, Tangerang was still at a low level. The reason was the school policy, with no program related to the involvement of parents and the financial and social economic status of parent.

\section{Attribution Theory}

Attribution is the process to understand the causes of events or behaviors oneself or in other people. Similarly, attribution explains the reasons behind the experiences and behaviors of oneself or others. Making attributions or conclusions about events or behaviors helps in understanding one self or others based on nature, purpose or certain capabilities. On the other hand, we cannot interpret the inferences of the characteristics of a person when observing their behavior. This is because we do not have access to the personal thoughts, motives, and feelings of others. However, by making such attributions, we can improve our ability to predict what is done by the person.

Attribution theory is a decision about the basis of a person's behavior. Attribution theory focuses on how people explain the behavior of others and their own behavior, and the consequences of the behavior in question. The basis of attribution theory is that people want to know the reasons for a behavior of themselves or others. Therefore, interpreting the behavior causes illustration of the behavior reasons. Briefly, attribution theory is concerned with how individuals interpret events and how this relates to their thinking and behavior.

In particular, our study focuses on the attribution theory which was developed by Bernard Weiner. His theory was most dominant in achievement. Weiner claimed that there are four causes within two dimensions within a 2 X 2 categorization which includes: ability, effort, task difficulty, and luck (Weiner et al. 1971, as cited by Weiner 1986).

First, the specific cause for ability is an internal factor which may be perceived as a stable if learning is possible. Second, an 
effort is also an internal factor often perceived as a stable trait, captured with the labels lazy and industrious, and the intent to work hard or not may be quite enduring. Next, the difficulty of a task as stable external factors can be changed to be more or less difficult, and the perceived difficulty of a task is in part dependent on one's ability and expenditure of effort. Last, luck is also a stable external factor which may be thought of as a property of the person (lucky or unlucky). The internal factors, called dispositional attribution consists of personality traits, motivation, ability, fatigue, and effort. Meanwhile, the external factors, called situational attribution, are factors such as equipment, rules, and social influence.

Thus, aptitude as an innate ability that will be better captured and trained continuously is a fixed capacity rather than ability; temporary exertion such as mood, motivation, and fatigue support the better effort; objective task characteristics depend on the level of difficulty of the task as a permanent type; and chance has an effect on equipment, rules, social influence, fate, and inadvertence.

Weiner (1985), as cited by Harvey and Martinko (2009), claimed that attribution behavior and the final result will help in forming the responses of emotion and behavior. Basically, the classifications of the causal dimensions of attribution are categorized into three dimensions in understanding the relationship attribution, emotional, and behavior process. Weiner $(1986,48)$ claimed that "a third dimension of causality was first suggested by Rosenbaum (1972)". Analyzing causality involves locus, stability and controllability. Each of these belonging is considered as a bipolar continuum, namely, internal-external, stable-unstable, and controllable-uncontrollable.

On the other hand, the external factors which can be seen from some views of the successful or failing person, influenced by the actions of people as accidental factors, become uncontrollable. In some cases, it can be changed by the personal effort and other internal factors such as mood and fatigue or due to the in- 
teraction between one person and another and also supported by the situation. The external causes uncontrollable pervade all external causes, but external causes are not all uncontrollable. For example, assume that a student's achievement is decreasing due to lack of parent involvement or influence by the social environment. This is an external cause which is uncontrollable by the student. However, the students are perceived as a subject that is influenced by parents or the social environment. The student would assume that these individuals are responsible for his or her success.

To summarize, the theoretical framework in this study is based on Epstein's typology which includes six different types of parent involvement. They are parenting, communicating, volunteering, learning at home, decision-making, and collaborating with the community. Each type of involvement has particular challenges that must be met in order to involve parents in schooling processes. That is why parents and school should be working together to support the success of their children. Parents can start by having important knowledge about their children, and by having the awareness to engage in their children's education. On the other hand, the school can develop more comprehensive programs to achieve important goals and meet the needs of its students and families. Moreover, we used attribution theory to understand the reasons for parent involvement in their children's education, such as the reasons for the parents' involvement or non-involvement.

In this study, the findings were categorized into three issues. First, the parents' understanding of their involvement in schooling processes. Second, the ways of communication between parents and school. Last, which parents were frequently involved in schooling processes. The findings would then be discussed based on the theoretical framework and the previous literature. 


\section{Parents' Understanding of their Involvement in Schooling Processes}

There were different perspectives about parents' involvement in schooling among the participants. The main perspective was that the school has more responsibility than parents in the learning progress for their children. Moreover, most of the parents were involved in the schooling process merely to respond to the school's invitation. The findings showed that they did not understand about parent involvement in the same way the school would like them to understand. There were several factors affecting parents' understanding of the school's expectation of parent involvement. Firstly, lack of information of parents was related to how they should be participating voluntarily in schooling processes, contributing to the school committee and collaborating with the community. Secondly, parents felt fear when they got a phone call from school. Thirdly, parents felt ashamed to visit the school. Lastly, parents did not understand the importance of their involvement for their children in learning at home.

\section{a. Lack of Information of Parents about School Expectations}

Volunteering in Schooling. The program held by the school to involve family or community is grouped into two classes: routine and non-routine programs. The routine program is the PTA (Parent Teacher Association), acquiring the academic report, and the Sukma Award. The school invited parents to attend school for those events. The non-routine program was without planning, for instance exhibitions or bazaars, the commemoration of national days, and guest teachers. The non-routine program not only involved parents in schooling but also in the community. The members of the school such as parents, school committee, and community around the school could come voluntarily to school, especially when school events were held.

The findings revealed that only a few parents were voluntarily involved in school events both routine and non-routine programs. Parent involvement as a volunteer in schooling pro- 
cesses was accommodated by the school. Parents attending school events were usually responding to school invitations. We argued that the parents did not participate more in schooling processes because they did not understand the importance of their involvement on improving their children's performances. Kimu and Stein $(2013,615)$ found that "teachers recognized that the parents' presence could encourage their children at these events, they did not regard this as part of a parent's role".

In this study, parents did not show initiative to attend to the school voluntarily. Parents had been involved in school events due to their obligations as parents in supporting the children in education. There was the perception that attending school was not an important thing, so that more likely someone could replace them in acquiring the report. In the same vein, P003 stated that she had never attended school for taking the academic report and her husband neither. She assumed that it was not an important thing to do, and her job as a teacher was more important than attending school events. She said that as far as her child was not in trouble in schooling processes, it meant there was no problem with her child's education. Thus, she could not come to school for taking her child's academic report and she suggested her sister replace her.

The school events could make the parents closer to the teachers. It enhances the interaction among the school members that affects to improve the school. Pomerantz et al. (2007) stated that parent involvement at school emphasized connecting through interaction with teachers. Daniel, Wang and Berthelsen (2016) stated that the activities of parent involvement at the school included communication directly or indirectly with teachers, also visiting the classroom and attending school events. We propose that the school provide a workshop for parents to increase their understanding of the school's expectations of volunteering.

Participating in the School Committee. Another program at the school that had not been conducted well was the school committee which is an organization to support the implementation of 
school programs, which parents know about the school programs through the school committee meeting. Some parents stated that they did not know the members of the school committee (P002, P003, P007, P008, P011, P012 and P013). According to P013, the role of the school committee was essential, however, it did not run well. This was supported by P008 who stated that parents had never been invited to the school committee meetings, and that was why they were not familiar with it. Based on P007's experiences, as a head of the school committee when his son was in the elementary school, the school committee would really assist the school to implement the school programs and help to solve problems at school. In reality, P009 recognized the names of the school committee of Sukma Bangsa. However, he never got the invitation from school to attend the school committee meeting. In addition, P010 mentioned the fact that parents were not getting information about the school committee neither on attending PTA and nor on taking the report.

The findings revealed that almost all parents did not know the names and the number of the school committee members. This means the process of determining the school committee members did not involve all the parents. In this case, the process of transparency in the school committee has not been done. In particular, this would encourage the parents to be actively involved in schooling processes. Kimu and Steyn (2013, p.617) found that "parents played a very limited role in decision making in schools". Therefore, the school committee is required to cultivate the values of democracy so that every decision made on the school policy and school program made would be more open. Furthermore, we argue that the difficulties which reduced participation were due to the lack of school socialization. Not one of the interviewed parents was part of the structure of the school committee.

The school committee has an essential role to support decision-making related to school policy by involving parents. Smith et al. (2011) said that making decisions aimed to involve for their suggestions about their children's learning process. Similarly, the 
school committee receives the aspirations of parents and bridges the gap between parents and school by decision-making not only by the school but also by the parents.

Collaborating with the Community. Basically, the participation of parents, school, and community should be balanced, because the children's success is influenced by environmental conditions from parents, school, and the community. However, the community environment had a greater influence on the children's attitudes to drugs and the internet. Through the positive activities at school, the children are able to protect themselves from the negative influences. On the other hand, P004 stated that teachers do not have enough time to work with parents in controlling every student, so interaction and communication among teachers and parents were really necessary.

Parent's participation with the community was creating relations and sharing responsibility to strengthen the school programs, family practices and their children's development. It was clear that collaborating with the community was limited and parents did not understand the benefits. Not one participant ever made a connection with the school related to improvement, but some parents communicated with other parents.

There are three cores of education in Indonesia based on the Law Number 23 of 2003 about the educational system in Indonesia. The three cores of education family, school, and the community have an important role in improving the quality of education. Parent involvement in schooling processes was one of the most important things to improve a school's goals and enhance self-confidence. When children thought that they had full attention, either from family or school, it affected to their willingness to learn. Therefore, all practitioners of education should provide several programs to involve the parents or the community so the quality of education in Aceh would be raised. 


\section{b. Parents Feeling Fear When Getting a Phone Call from School}

If the parent got a phone call from school, especially from the homeroom teacher, it meant that their children were in trouble, even if the phone call was only to announced school fees or the children's progress. This was confirmed by parents who reported:

If school contacts the parents, it was regarding some bad news which they did not want to hear. The first thing which teachers said about my child that emerged in my mind was fighting or scoring. But, if the school calls a parent because my child gets good achievements it would make me shocked (P003).

I got a phone call from school because my son disobeyed the school rules, so that when I get another call I feel fear. What appeared to my mind was my son must have done something wrong again. Even though, in that moment, the teacher just talked about school activities, like a parade (P002).

P003 as a homeroom teacher in public school added that, based on his experiences, he just called the parents when their children in trouble, which makes parents feel fear, and be disappointed in themselves. In contrast with P003, one parent said they had no need to feel a fear of a school phone call because it means the school cares for and respects their children. Likewise, it was a good way to communicate with parents. Additionally, P001 explained:

I was really thankful to the homeroom teacher if they called me told about my son. The communication was really helpful for me as a parent to overcome learning difficulties that were faced by my children so that I know what I should do to help my child.

The most common reason that the teacher contacted the parents by phone was to discuss the difficulties of the student in learning, often after the examination or delivering students' reports. As P005 noted he was angry with his son after got the 
phone call from school. He felt disappointed because his son did not complete the homework, which lowered his achievement. In contrast to P005, P003 said that she never got a phone call from school related to the difficulties of her daughter in learning, so her child is not in trouble. One parent who was angry with the teacher because of a phone call explained:

I got the phone call from principal related to my son achievement in learning. I know about the competency of my son in learning and there are several subjects that he cannot complete properly, and he should take remedial classes. In that moment, I was really angry with the principal because he was asking me to attend school. I said that should I come to school now? But, I could not come to school because I was still working. Then, I asked my wife to go to school. I realized that I am never involved in schooling processes of my child. I just focus on working and fulfilling the financial needs. My wife had the responsibility regarding school matters.

Some parents in this study said that they felt nervous, worried and fearful when they attended school for their children's academic report. One of the assumptions was that it was likely that the problem was very serious, one adding that she would be ashamed to come to school if the child did not pass. In the same vein, P008 noticed that he and his wife feel ashamed and angry when the school explained that their children disobey the rules. According to P004, if the simple matter is a learning problem, it could be solved by a mother. However, concerning the fights a father's role was to handle it, these findings show that most of the parents have perceptions of worry concerning phone calls from school because it was impossible that the school will contact them with good news. The most common contact by phone was something urgent which needed to be solved directly. Consequently, the school should consider how to change the perception of parents regarding the phone calls from school. 


\section{c. Parents Feeling Ashamed to Attend School}

In addition, every student had the same opportunity to participate in any activities at school. P005 stated that there was no difference between students from the middle economic status and the high economic status in this school, so that his son did not feel ashamed to interact with another student. Moreover, the school's environment also promoted a positive environment to interact with each other. P005 add that the important benefit that he got from the school was that his children have "civilized behavior". When the school had a positive environment, it would affect student behavior. This was confirmed by a parent who mentioned that she wanted to do the best for her children in education, so that she preferred to enroll her son in a school which has a good environment. The atmosphere in the school was welcoming toward parents.

Most of the parents who were involved in this study feel enthusiastic about coming to school, but the obstacles are time and job pressures. As parents who had entrusted the school to educate their children, it was supposed there was no need to feel ashamed when with the teacher. As an institution, the school has the responsibility to create a good environment and be welcoming of parents and also embrace the parents as part of the school community. One parent said that what makes him ashamed to participate if the school invites him is if his child is in trouble or had done bad things. In contrast, P012 explained:

I feel ashamed attending school. I feel the teacher in the school is more knowledgeable than me and the circumstance is merely suitable for someone who has high knowledge. Because of that feeling, I never come to school, both in taking academic reports and school events.

The findings revealed that the parent's perceptions of attending school meetings such as the PTA and the collection of academic reports related to their own feelings about the teachers' qualification. They think the teachers are more knowledgeable than them so that they feel ashamed to come to school. Further, 
the parents had the assumption about the quality of the teachers closely related to the good learning environment at school. That is why the parents very selectively chose the appropriate school for their children. Most of the parents had the same desire in choosing their children's education related to the school's learning environment. The motivation of the parents to choose the school because they felt safe to enroll their children into the best school.

\section{Parents Did Not Understand the Importance of Their Involvement in Learning at Home}

All parents provided facilities in order to help their children accomplish their homework. The tools that offered by parents were laptops and smart phones that were always equipped with internet data packages. The internet was the solution for completing difficult tasks given by teachers. One of the facilities in helping children to do homework or task of the school was a smart phone, which for example, could be used for searching on the internet (P002). Furthermore, the other solution that was provided by parents was by purchasing books which provided answer keys, and by asking for help from other people, such as their neighbor, who were experts in the materials related to the homework.

Therefore, parents did not ask their children very often whether they had finished their homework or not. Children would resolve the difficulties they encountered in doing their homework by themselves, for instance, by seeking information from books or the internet (P016). In addition, another way that was made by parents to overcome the difficulties their children had in the learning was by inviting a private teacher. Generally, mathematics and English were subjects that required reinforcement from people who were experts in the field.

In this study, we found that the role of parents for homework assistance was very low. It was indicated by the parents' statements that they seldom helped their children in doing homework. 
In the present study, they monitored their children in completing homework (Smith, Wohlstetter, Kuzin, \& Pedro 2011), and reminded their children to complete the homework. Parent involvement in learning at home was triggered by different factors, such as parents' perception of school age and assisting, parents' perception of their children's autonomy (Cunha, et.al. 2015), parents' perception of learning, and the limitation of parents' knowledge in understanding learning material.

Parents had a perception that they should encourage independence and responsible behavior in learning when their children were at school age (e.g. elementary school). They perceived that, in elementary school, the children needed more assistance from their parents in doing homework rather than in junior high school, so that when the children moved to junior high level, the parent involvement in studying would be decreased. According to Gonida and Cortina (2014), parents' independence support and control in doing homework eased in 8th graders, while parents' intervention and cognitive involvement were still the same. Núñez, et.al (2015) found that perception of parent involvement in homework was significantly related to student homework behavior. At this level, the important role of parents was to direct their children. In a similar vein, parent involvement in learning at home denoted raising their autonomy, developing, and monitoring their learning (Cunha, et.al. 2015). However, the parents recognized that children at primary school level needed their assistance or guidance more than the children at secondary or upper secondary level.

Parents' perception of learning also inhibited their involvement at home. The motivation of parents to involve in doing their children homework was caused by their concern about better grades. They worried that their children would be failed, and the parents thought that it would be ashamed. In addition, the other motivation of parents in caring and controlling learning at home was still at a very practical level, yet at a higher level. If the children had finished their homework, it meant that monitoring the learning had also been completed. Parents were worried more if 
their children did not complete their homework rather than their understanding of the material taught. Some parents perceived that learning at home was merely on completion of homework or assignment. If their children were doing homework, it meant that their children were studying. Thus, when the teacher did not give assignments, the children did not study.

Parents' perception of learning at home for their children was only for completing homework. They did not investigate what should be learned by their children at certain levels according to their respective subjects. The limited understanding of learning at home for the parents was that their children were able to do their homework based on the students' worksheets. This includes elements that threaten the concept of learning; the child becomes a technical person as an implication. The children simply did what they were told without their own initiative. Supposedly, parents create learning conditions at home that make the children become learners for themselves. Thus, the meaning of learning is not only to complete the tasks but also to acquire knowledge, which results in changes in the management of knowledge, attitudes, and behavior. For most of the parents in this research, the comprehension of learning was at the stage of completing the task, even though the homework was just a small part of learning.

Limited knowledge about the subject also became an obstacle to parents in assisting their children in completing the task. Not only to parents, who perceived the lack of knowledge in accordance to the subject, but also their children. Therefore, children perceived that the parents assisting in doing homework was not necessary. Nevertheless, parents underlined the importance of monitoring their children to complete the homework, for example by providing facilities such as a gadget for internet access and books consisting of exercises to overcome the difficulties in doing homework. Some parents acknowledged collaborating with their children to cope with difficult assignments (Cunha, et.al. 2015). 
Additionally, one of the parents acknowledged that she perceived the children would not be comfortable if the mother was supervising them while they were doing homework. This was supported by Kimu and Steyn (2013), who found that parents have a lack of confidence to support their children's education at home. The parents had business with work and taking care of they youngest children and domestic arrangements, while her husband worked out of town and rarely had time with the family. We assume that it only informal communication happened, and the parentsonly met the needs of the learning course, while the children's psychological needs were not met.Thus, there was no closeness between parents and children.

Furthermore, the parents encountered difficulties in guiding their children at home especially in finishing homework. Parents did not consult with their children's teacher about student homework difficulties and progress. They preferred to ask their colleague or invite a private teacher to cope with the problem. The aim of their involvement was only the completion of their children's homework and to get a better grade at school. Therefore, we argue that parent involvement in learning at home was still not optimal. Parents did not have a better understanding related to parent involvement in learning.

\section{Communication Between Parents and School}

Types of Communication. The communications between parents and schools were through mail, byphone, face to face, and the SISTO (Integrated School Information System Online). Mail was used to invite parents to come to school's events such as the Parent Teacher Association(PTA), academic report collection, workshops, school fair, and bazaar. In addition, mail was used when student had trouble at school. On the other hand, SISTO is an automatically system that aims to facilitate communication to parents and the school community e.g. to inform parents about the tuition fee each mid-semester (every three months). However, the phone was commonly used by parents to contact 
the school. In addition, the homeroom teacher contacted parents to remind their children in following remedial programs and is one of the ways to involve parents. Therefore, some parents said that the communicates with them by phone about their children's progress, problems, and behavior at school.

P011 said that the most effective communication was face to face, which the parents preferred rather than phone. Face to face communication also can foster the relationship with another parent. A different view, fromP010, was that the most accepted communication which is conducted by parents to school depends on their children's problems. If children are in trouble, then the best solution was to face to face. If the children did not have a serious problem, it could be done by phone or letter. This is supported by $\mathrm{P} 014$ who said that the most effective communication for serious things was face to face.

Two-Way Communication. Communication with the school initiated by parents was to collect their children's academic report or provide the information that their children could not attend school. On the other hand, communication initiated by the school was giving the information about their children's development. Some of the parents communicated with the school mainly to the homeroom teacher and only did it when they took their children's academic report every quarter and discussed it with the homeroom teacher, including about their children's development at school and parents felt dissatisfied if the student's grades decreased in learning. In this case, this represents an unstable attribution caused by effort as internal factors that parents foster their children in learning. Parents need to support their children in schooling, which can be seen by them paying attention to the academic report. While the parents tried to clarify if it was not really satisfactory, they did not reflect on their influence.

The parents understood that communication with the school was very important e.g. when they asked about the causes of low grades or asked the homeroom teacher about their children's behavior with friends or teachers. Hill and Tyson (2009, 
p.758) claimed that "among the types of involvement, parental involvement that creates an understanding about the purposes, goals, and meaning of academic performance; communicates expectations about involvement; and provides strategies that students can effectively use (i.e., academic socialization), (which) has the strongest positive relation with achievement". In brief, some parents assumed that they did not need to contact the school if their children did not have a problem e.g. if their children's grades were satisfactory. They communicated with the teachers only when they paid the tuition fee and picked up their children from school. Nevertheless, a few of them still contacted school routinely to know more about their children's development.

Most of the parents that were asked how often each month, on average, the school contacted them through letter, phone, or face to face concerning parent-teacher meetings answered that the school did not routinely contact them and only when their children had a problem. As well, the school informed about the tuition fee to parents by phone every three months in a midsemester. However, the parents contacted the school or came directly to the school at least once in a month, although some did not routinely communicate with teachers. Some parents realize that they did not have the best understanding when they did not have a good relationship and communication with the teachers. For this reason, the parents should be aware of the importance of parent involvement in schooling processes and actively communicate with the teachers to know about their children's development at school.

\section{Which Parents Are Frequently Involved in Schooling Processes?}

Basically, all of the parents were concerned and would have liked to be involved but there was limited understanding of the importance of parent involvement, not only at home but also at school, was a factor. However, most of the participants 
recognized their responsibilities and obligations as parents in providing their children with basic needs, as emphasized by Epstein's framework, in rearing, guiding, and educating them.

Being successful in the future. Specifically, most of the parents' emphasized education as the most important thing for their children in shaping their character for success in the future. Likewise, knowledge is the vital key that can help someone in facing the world. When we asked the parents about the aim of parent involvement, almost all expected their children would have a better life through a good education. The indicators of success in education according to some parents in this study were higher scores and getting a ranking which showed that their children could perform well at school. On the other hand, some parents said that the gauge of victory was independence. It meant their children were able to fulfill their own needs without having to rely on their parents.

Based on the analysis, a variety of parent involvement was revealed in this study: taking children to school, caring for health, delivering lunches, teaching discipline, facilitating learning, communicating about school, monitoring the children's development, preparing their children for school, providing money for snacks, monitoring the associations of children outside school, and motivating children to learn.

Good manners. P004 and P005 said that one aspect of parent involvement was selecting the best school for their children, because a good school will impact the children's attitudes and achievement. The majority of parents were applying a reward and punishment system. If the children obtained the achievements e.g. better grades in school then they would be rewarded by such as buying things, leisure travel, or granted a wish. Conversely, if the children make a mistake or violated the rules t either at home or at school, they would be reprimanded, warned or their pocket money would be reduced.

The characteristics nurtured by Acehnese people include hard and firm discipline and, in the past, violence towards 
children frequently occurred, and parents did not hesitate. P005 who stated that if the children made mistakes and did not want to listen toparents, then he would threaten or even hit his child, which was his own experience as a child. Against this, P001 said that, nowadays, parenting strategy is different to the previous period. Today, the children are more critical, and dared to criticize every action taken by the parents; children in the previous era immediately obeyed their parents, and never asked about the purpose or explanation. Therefore, the discipline of parents and resolution in parenting was needed.

Parents' strategy in rearing and educating their children is affected by the construction of their children's characters and the interaction with the environment, including social interaction with family, school, and community. Overall, the fourteen participants believed that family environment had the most influence, as the first place where children learn. If the children's behavior at home was good, then the behavior at school and in the community would also be good. They imitate the attitude and aptitude of their parents.

Differing perceptions of parent involvement are a factor in their participation in schooling. Some parents never came to meetings, even the distribution of report cards, which is an important moment, and demonstrates the level of parent involvement at home. This is an opportunity for parents to communicate with school staff and the homeroom teacher. Most of the parents who participated in taking the academic report were a mother (81.25\% of total informant). Mothers were more involved than fathers. According to P004, P008, and P016, who were fathers, the mother had a greater responsibility in educating children, while for a father it was natural to meet the economic needs. Even if both of parents were working and busy with their job, mothers should attend school. However, a father would accept the duty when children were fighting at school and the mother was not available. Therefore, they expected that mothers know better about the children and have to be close to them. 
In summary, the parents had self-perception about caring and raising their children. Getting married meant they were ready for all the consequences of having children. As P005 emphasizes, if parents did not want to be involved, it was better not to have children. P010 noted that nothing was too difficult for parents who believe that it is an obligation. Parents should have a basic comprehension of parent involvement, and school or educators should provide training.

These findings concur with the theoretical framework of Epstein (2001, 2011), who said that the basic obligation of families is to fulfill the students' needs. What is needed is assisting families with parenting skills, building the discipline and motivation of students, paying tuition fees on time, and solving the constraints of being a parent.

\section{Conclusions}

On the whole, the results of this study, based on Epstein typology of parent involvement, show that most of the parents in the Aceh school did not understand the importance of the role of parent involvement in schooling processes. Parents had different perceptions of the school's expectations of their involvement. The most important thing understood by the parents was about parenting, but they did not really have a good knowledge about the other types of parental involvement mentioned by Epstein's, such as howparents' communication with school depended on the problems of their children. In learning at home, the parents were more controlling than monitoring e.g. whether their children are studying at home not if they finished their homework. Concerning volunteering, the parents never offered to be a volunteer, such as a guest teacher. In decision making, they never offered their opinions about the school programs to teachers or the community.

Finally, the division of everyday jobs and responsibilities within the family between father and mother are an impediment to parent's involvement in schools. The parent still perceives 
that the work of a mother in any form is not categorized as busy even though they are both working. However, mothers should be able to divide their time between working at home and being active outside the home. The responsibility of the father is seen as to provide the needs of families at home, with responsibility for "violence" such as fighting at school, where the father is expected to contribute. Meanwhile, the perceived responsibility of the mother is to raise children, take care of the household and support their children's education. The mother is also responsible for "softness" issues, such as assisting their children in homework and attending school events. Given this understanding, mothers are more likely to engage in any events related to the development and achievement of their children at school and in the society. This was revealed by the percentage of mothers present at the school meetings, including the distribution of students' academic reports, where they were more frequently present than fathers. 


\section{BIBLIOGRAPHY}

Alsheikh, N. O., Parameswaran, G., \& Ethoweris, H. 2010. "Parenting Style, Self Esteem and Student Performance in the United Arab Emirates." Current Issues in Education 13 (1).

Anfara Jr, V. A. and Mertens, S. B. 2008. "Varieties Of Parent Involvement in Schooling." Middle School Journal 39 (3): 58-64.

Ardelt, M. \& Eccles, J. S. 2001. "Effects of Mothers' Parental Efficacy Beliefs and Promotive Parenting Strategies On InnerCity Youth." Journal of Family Issues 22 (8): 944-972.

Assalahi, H. 2015. "The Philosophical Foundations of Educational Research: A Beginner's Guide." American Journal of Educational Research 3 (3): 312-317.

Baedowi, et all. 2005. Blueprint of Sukma Bangsa School. Jakarta: Yayasan Sukma Media Group.

Bandura, A. 1994. “Self-efficacy.” In VS Ramachaudran. Encyclopedia of Human Behavior. vol. 4.

Baxter, P. \& Jack, S. 2008. "Qualitative Case Study Methodology: Study Design and Implementation For Novice Researchers." The Qualitative Report 13 (4): 544-559.

Bronfenbrenner, U. 1986. "Ecology of The Family as A Context For Human Development: Research Perspectives." Developmental Psychology 22 (6): 723.

Brown, J. R., Knoche, L. L., Edwards, C. P., \& Sheridan, S. M. 2009. "Professional Development To Support Parent Engagement: A Case Study of Early Childhood Practitioners." Early Education and Development 20 (3): 482-506.

Chen, W. B. \& Gregory, A. 2009. "Parental Involvement as A Protective Factor During the Transition To High School." The Journal of Educational Research 103 (1): 53-62.

Colley, B. M. (2014). “Voices from The Gambia: Parents' Perspectives on Their Involvement In Their Children's Education." Childhood Education 90 (3): 212-218.

Cunha, J., Rosário, P., Macedo, L., Nunes, A. R., Fuentes, S., 
Pinto, R., \& Suárez, N. 2015. "Parents' Conceptions Of Their Homework Involvement in Elementary School." Psicothema 27 (2), 159-165.

Daniel, G. R., Wang, C. \& Berthelsen, D. 2016. "Early School-Based Parent Involvement, Children's Self-Regulated Learning and Academic Achievement: An Australian Longitudinal Study." Early Childhood Research Quarterly 36: 168-177.

Deslandes, R. \& Bertrand, R. 2005. "Motivation of Parent Involvement in Secondary-Level Schooling." The Journal of Educational Research 98 (3): 164-175.

Deslandes, R. (ed.). 2009. International Perspectives on Contexts, Communities and Evaluated Innovative Practices: FamilySchool-Community Partnerships. London: Routledge.

El Nokali, N. E., Bachman, H. J. \& Votruba-Drzal, E. 2010. "Parent Involvement and Children's Academic and Social Development in Elementary School." Child Development 81 (3): 988-1005. Epstein, J. L. (1987). "Parent Involvement: What Research Says To Administrators?” Education and Urban Society 19 (2): 119-136.

Epstein, J. L., Sanders, M. G., Simon, B. S., Salinas, K. C., Jansorn, N. R., \& Van Voorhis, F. L. 2002. School, Family, and Community Partnerships: Your Handbook for Action. Corwin Press.

Epstein, J. L. 2010. "School/family/community Partnerships: Caring for the Children We Share: When Schools Form Partnerships with Families and the Community, the Children Benefit. These Guidelines for Building Partnerships Can Make It Happen." Phi Delta Kappan 92 (3): 81.

Fan, X. and Chen, M. 2001. "Parental Involvement and Students' Academic Achievement: A Meta-Analysis." Educational Psychology Review 13 (1): 1-22.

Fitriah, A., Sumintono, B., Subekti, N. B. and Hassan, Z. 2013. "A Different Result of Community Participation in Education: An Indonesian Case Study of Parental Participation in Public Primary Schools." Asia Pacific Education Review 14 (4): 483- 
493.

Froiland, J. M., Oros, E., Smith, L., \& Hirchert, T. 2012. "Intrinsic Motivation To Learn: The Nexus Between Psychological Health and Academic Success." Contemporary School Psychology: Formerly “The California School Psychologist” 16 (1): 91-100.

Georgiou, S. N. 1996. "Parental Involvement: Definition and Outcomes." Social Psychology of Education 1 (3): 189-209.

Gonida, E. N. \& Cortina, K. S. 2014. "Parental Involvement in Homework: Relations With Parent And Student AchievementRelated Motivational Beliefs and Achievement." British Journal of Educational Psychology 84 (3): 376-396.

Gutman, L. M. and Midgley, C. 2000. "The Role of Protective Factors in Supporting the Academic Achievement of Poor African American Students During The Middle School Transition." Journal of Youth and Adolescence 29 (2): 223-249.

Harvey, P. and Martinko, M. J. 2009. "Attribution Theory and Motivation." Organizational Behavior, Theory And Design in Healthcare.

Hill, N. E. and Tyson, D. F. 2009. "Parental Involvement in Middle School: A Meta-Analytic Assessment of the Strategies that Promote Achievement." Developmental Psychology 45 (3): 740.

Holloway, S. D., Yamamoto, Y., Suzuki, S., and Mindnich, J. D. 2008. "Determinants of Parental Involvement in Early Schooling: Evidence from Japan." Early Childhood Research \& Practice 10 (1).

Hoover-Dempsey, K. V., Battiato, A. C., Walker, J. M., Reed, R. P., De Jong, J. M., \& Jones, K. P. 2001. "Parental Involvement in Homework.” Educational Psychologist 36 (3): 195-209.

Hornby, G. 2011. Parental Involvement in Childhood Education: Building Effective School-Family Partnerships. Springer Science \& Business Media.

Hornby, G. and Lafaele, R. 2011. "Barriers to Parental Involvement in Education: An Explanatory Model.” Educational Review 63 
(1): 37-52.

Hornby, G., \& Witte, C. 2010. "Parent Involvement in Rural

Elementary Schools in New Zealand: A Survey." Journal of Child and Family Studies 19 (6): 771-777.

Houtenville, A. J. and Conway, K. S. 2008. "Parental Effort, School Resources, And Student Achievement." Journal of Human Resources 43 (2): 437-453.

Ibrahim, A. T., \& Jamil, H. B. 2012. "The Nature of Parental Involvement in the Schooling Process in Katsina State." Journal of Education and Learning 1(2): 37.

Karsidi, R., Humona, R., Budiati, A. C. \& Wardojo, W. W. 2014. "Parent Involvement on School Committees as Social Capital to Improve Student Achievement." Excellence in Higher Education 4 (1): 1-6.

Kimu, A. M., and Steyn, G. M. 2013. "Applying the Epstein Model to Investigate Parent Involvement in Public Primary Schools in Kenya." Journal of Asian and African Studies 48 (5): 607-622.

Kocayörük, E. and Şimşek, Ö. F. 2016. "Parental Attachment and Adolescents' Perception of School Alienation: The Mediation Role of Self-Esteem and Adjustment." The Journal of psychology 150 (4): 405-421.

Larsson, J. \& Holmström, I. 2007. "Phenomenographic or Phenomenological Analysis: Does It Matter? Examples From A Study on Anaesthesiologists' Work." International Journal of Qualitative Studies on Health and Well-being 2 (1): 55-64. Merriam, S. B. and Tisdell, E. J. 2015. Qualitative Research: A Guide to Design and Implementation. John Wiley \& Sons.

Monson, L. and Myers, J. 1992. Involving Families in Middle Level Education. Columbus, OH: National Middle School Association. Onwuegbuzie, A. J., \& Leech, N. L. 2007. "Sampling Designs in Qualitative Research: Making the Sampling Process More Public." The qualitative report 12 (2): 238-254.

Olmstead, C. 2013. "Using Technology to Increase Parent Involvement in Schools.” Techtrends 57 (6): 28-37. 
Patrikakou, E. N., \&Weissberg, R. P. 2000. "Parents' Perceptions Of Teacher Outreach And Parent Involvement In Children's Education." Journal of Prevention \& Intervention in the Community 20 (1-2): 103-119.

Patrikakou, E. N. and Anderson, A. R. (eds.). 2005. School-Family Partnerships for Children's Success. Teachers College Press. Pietkiewicz, I. and Smith, J. A. 2014. "A Practical Guide To Using Interpretative Phenomenological Analysis in Qualitative Research Psychology." Psychological Journal 20 (1): 7-14.

Pomerantz, E. M. and Eaton, M. 2001. "Maternal Intrusive Support in The Academic Context: Transactional Socialization Processes." Developmental Psychology 37 (2): 174.

Pomerantz, E. M., Moorman, E. A. and Litwack, S. D. 2007. "The How, Whom, And Why of Parents' Involvement In Children's Academic Lives: More Is Not Always Better." Review of Educational Research 77 (3): 373-410.

Majzub, R. M., \& Salim, E. J. H. 2011. "Parental Involvement In Selected Private Preschools In Tangerang, Indonesia." Procedia-Social And Behavioral Sciences 15: 4033-4039.

Margarete, S. 1995. "Focus on Qualitative Methods Sample Size in Qualitative Research." Research in Nursing \& Health 18: 179-183.

Núñez, J. C., Suárez, N., Rosário, P., Vallejo, G., Valle, A., \& Epstein, J. L. 2015. "Relationships Between Perceived Parental Involvement in Homework, Student Homework Behaviors, And Academic Achievement: Differences Among Elementary, Junior High, And High School Students." Metacognition and Learning 10 (3): 375-406.

Reynolds, A. J. 1992. "Comparing Measures of Parental Involvement And Their Effects On Academic Achievement." Early Childhood Research Quarterly 7 (3): 441-462.

Samad, S. A. A. 2015. "Character Education Base on Local Wisdom in Aceh (Study On Tradition Of Children Education In Aceh Community)." Al-Ulum 15 (2): 351-370. 
Sandjaja, S. 2001. "Pengaruh Keterlibatan Orang Tua Terhadap Minat Membaca Anak Ditinjau Dari Pendekatan Stress Lingkungan." Psikodimensia Kajian Ilmiah Psikologi 2(1): 17-25.

Sapungan, G. M. and Sapungan, R. M. 2014. "Parental Involvement In Child's Education: Importance, Barriers And Benefits." Asian Journal of Management Sciences \& Education 3 (2): 23-43.

Shah, R., \& Cardozo, M. L. 2014. "Education and Social Change In Post-Conflict And Post-Disaster Aceh, Indonesia." International Journal of Educational Development 38: 2-12.

Smith, J., Wohlstetter, P., Kuzin, C. A., \& De Pedro, K. 2011. "Parent Involvement In Urban Charter Schools: New Strategies For Increasing Participation." School Community Journal 21 (1): 71.

Sohn, S., \& Wang, X. C. 2006. "Immigrant Parents' Involvement In American Schools: Perspectives From Korean Mothers." Early Childhood Education Journal 34 (2): 125-132.

Sui-Chu, E. H., \& Willms, J. D. 1996. "Effects of Parental Involvement On Eighth-Grade Achievement." Sociology of Education.

Sumargi, A., Sofronoff, K., \& Morawska, A. 2015. "Understanding Parenting Practices and Parents' Views Of Parenting Programs: A Survey Among Indonesian Parents Residing In Indonesia And Australia." Journal of Child And Family Studies 24 (1): 141-160.

Van Der Werf, G., Creemers, B., \& Guldemond, H. 2001. "Improving Parental Involvement in Primary Education in Indonesia: Implementation, Effects And Costs." School Effectiveness And School Improvement 12 (4): 447-466.

Weiner, B. 1986. "An Attributional Theory of Achievement Motivation and Emotion." In An Attributional Theory of Motivation and Emotion. US: Springer.

Wilder, S. 2014. "Effects of Parental Involvement On Academic 
Achievement: A Meta-Synthesis." Educational Review 66 (3): 377-397.

Yetti, R. 2012. "Pengaruh Keterlibatan Orang Tua Terhadap Minat Membaca Anak Ditinjau Dari Pendekatan Stres Lingkungan. Pedagogi 9 (1): 17-28.

Yin, R. K. 2003. Case Study Research Design and Methods Third Edition Applied Social Research Methods Series. CA: Sage Publications.

Yoder, J. R., \& Lopez, A. 2013. "Parent's Perceptions Of Involvement In Children's Education: Findings from A Qualitative Study of Public Housing Residents." Child and Adolescent Social Work Journal 30 (5): 415-433. 